\title{
Faculty and Student Attitudes toward Credit Courses for Library Skills
}

\author{
Jeanne R. Davidson
}

\begin{abstract}
Faculty, student, and library staff attitudes toward credit courses, as well as various other instructional methods, for teaching library and research skills were assessed. A surprising number of faculty and students did not know about the courses offered. Although other methods, such as Web tutorials and written guides, are preferred, credit courses may still be considered a viable option. To be successful, the courses must be well marketed to both faculty and students, and their importance and content must be clearly understood by faculty advisors.
\end{abstract}

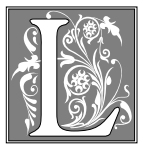

ibraries have used credit classes as one method of teaching library and research skills to students for many years. A 1995 survey conducted by the LOEX Clearinghouse for Library Instruction reported that 30 percent of libraries offer basic library skills courses or academic subject area library research classes for credit. ${ }^{1}$ Credit courses have been used consistently since 1987 at the institutions surveyed. Other methods such as lectures, computer-assisted instruction, videotapes, and pathfinders or guides also have been used consistently since $1987 .^{2}$

The relative merits of these various methods also have been debated for many years. Several studies have documented the effectiveness of credit courses for improving students' knowledge of library and research skills using pretests and posttests of student learning. ${ }^{3}$ Credit courses continue to be developed and added into some college and university curricula, whereas other universities have discontinued for-credit library courses., ${ }^{4,5}$

\section{Research Questions}

Despite these evaluations and long-standing debates, little research is reported on what value faculty and students place on credit courses. Do the faculty and students consider instruction in library and research skills important? What methods of instruction do they prefer? What are they willing to use? How much administrative support is necessary for credit classes? This paper reports on a study addressing these questions.

\section{Background}

Librarians at Oregon State University (OSU) teach several one-credit, disciplinespecific library research courses for academic departments. In 1998, the library assessed the importance of these classes to the faculty and students as part of an overall review of the services provided to the campus by Information Services (IS). ${ }^{6}$ The courses reviewed included:

- AG 111 Computers in Agriculture: One credit of this three-credit course focuses on the importance of preplanning 
and effectively using electronic resources, including the Internet, to find and evaluate agricultural information.

- ALS 112 Computer Technology Survival Skills: One-credit, pass/no-pass course introduces students to technologies provided by IS, including e-mail, library/Web research, PowerPoint, and HTML.

- CH 507 Chemical Information Seminar: One-credit topic in the Chemical Seminars series focuses on finding and evaluating print, electronic, and Webbased chemical information.

- ENG 200 Library Skills for Literary Study: One-credit class required for English majors focuses on finding, evaluating, and utilizing information resources in literature.

- ENGR 485/585 Comprehensive Literature Searching in Engineering: One-credit course focuses on finding and evaluating print, electronic, and Web-based engineering information.

\section{Methodology}

The review process included gathering information in three areas: surveying external stakeholders (those outside IS) and internal stakeholders (those within IS), estimating the cost of providing the service to determine cost-effectiveness, and comparing practices at peer institutions. Finally, a written recommendation based on the information gathered was given to IS administration regarding the need for continuation of the service. The five reference librarians who teach the courses conducted the review, assisted by the head of reference and an outside facilitator who helped develop the process.

The first step in gathering the information required identification of key stakeholders for the service. Students are obviously a primary external stakeholder group. Faculty were considered in two groups: general faculty not directly associated with a department for which a class is taught; and faculty in departments for which courses are taught, including department chairs and head advisors in each department or college. In- ternal stakeholders included all members of the reference department and managers for other areas within Information Services.

\section{External Stakeholders Surveys}

Surveys for external stakeholders were distributed using a variety of methods. The survey for students was conducted using paper questionnaires handed out at OSU's Memorial Union and Web-based forms prominently displayed on the library's computer stations; 234 responses were received. The surveys for students focused on: their perceptions of the importance of instruction for various library and research skills, their perceptions of the usefulness of various teaching methods for learning these skills, their awareness of these credit courses, and whether they had taken one of these courses (or a similar one elsewhere).

\section{To document practices at other institutions, library instruction coordinators at eleven peer institu- tions were contacted by phone.}

The survey for general faculty was conducted via e-mail. The subject librarian responsible for liaison with each college or department sent an e-mail copy of the survey and the URL for the Webbased faculty survey to their departments; nineteen responses were received. The surveys for general faculty focused on their perceptions of the importance of instruction for various library and research skills, their perceptions of the usefulness of various teaching methods, their awareness of any of these credit courses, and whether they recommended any of these courses to their students.

The methods of distribution for students and general faculty are clearly selfselected in favor of those who regularly use the library, have a potential interest in library instruction, and are proficient with electronic media. No attempt was made to ensure a statistically valid sample size or representation for either of these groups. 
Because of the importance of information from the departments for which the courses are taught, these faculty, head advisors, and department chairs were contacted by phone; forty-four responses were received. Survey questions for this group focused on their awareness of the courses; whether the courses were or were not recommended to students; if the courses were not recommended, why not; the impact of the class on students' ability to find and evaluate information (for chemistry and English faculty); and the likelihood of the class continuing without instructors provided by the library.

\section{Internal Stakeholders Surveys}

Internal stakeholders were surveyed by e-mail. The survey for reference staff, which received ten responses, focused on their perceptions of the importance of credit classes in supporting the university's educational mission and goals; the perceived impact on staff workloads; the importance of teaching credit classes for professional development; their perceptions of the importance of various teaching methods; and their perceptions of the "political" importance of teaching credit classes.

Questions for IS managers, which received four responses, emphasized their perceptions of the importance of credit classes in supporting the university's educational mission and goals; their perception of the cost-effectiveness of the classes; the importance of teaching credit classes for professional development; their perceptions of the political importance of teaching credit classes; and the perceived impact of credit classes on staffing.

To assist in assessing the cost-effectiveness of the courses, the managers were provided an estimated cost of teaching the courses. The cost estimate was based on expenses for personnel, services and supplies, capital expense, and revenue generated by the classes. The cost for personnel included the librarian FTE for teaching, classified staff, and student time involved in materials preparation, course administration, and/or teaching assis- tance. Services and supplies costs included primarily duplicating and printing costs and any online searching charges. Capital expenses are those incurred for facilities.

\section{Comparison with Other Institutions}

To document practices at other institutions, library instruction coordinators at eleven peer institutions were contacted by phone. In addition, a survey was conducted on BI-L, a large library instruction e-mail discussion list, which received twenty-six responses. Questions for both groups focused on whether credit classes are offered, whether other academic faculty are involved in library credit course development, the presence of information literacy standards, reimbursement to the library for credit classes taught, availability of other credit classes focusing on library/research skills on campus, and other methods used for library instruction including level of faculty involvement.

\section{Summary of Results \\ External Stakeholders}

Students clearly find instruction for various aspects of library research important (see figure 1). Most useful instructional method from the student perspective is more variable. Summing across the number of student responses of three or better (three is "would consider," five is "would prefer to use"), students indicated a preference for Web-based tutorials with written guides and assignments a close second (see figure 2). Single-session workshops were next and credit classes were the least preferred method.

Even though credit classes are the least-preferred method, approximately 63 percent of student respondents indicated they would consider taking a credit class as a means of learning library research skills. In contrast, 72 percent indicated they would take one of the described classes if it were relevant to their major. Clearly, students will be more receptive to credit classes if they understand the relevance of the course to their majors. 


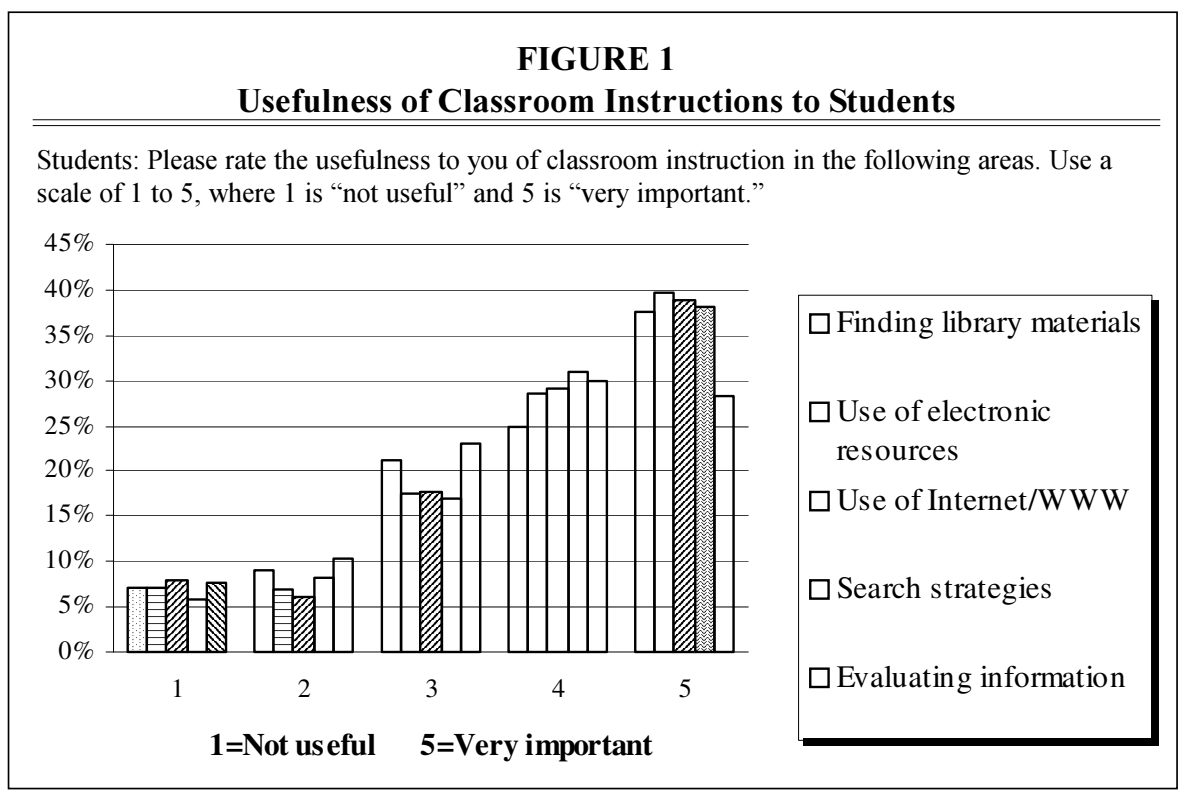

Only 23 percent of students were aware of the classes offered, and only 9 percent had participated in one of the classes offered.

Most of the general faculty responding to the survey rated instruction for the various aspects of library research at the highest level of importance (see figure 3). More faculty considered Web-based tuto- rials potentially useful than did students (see figure 4, summing responses of three or better). Credit courses were considered least useful and less potentially useful by faculty than by students (approximately $55 \%$ of faculty rated credit courses at three or better versus $63 \%$ of students).

Of the general faculty responding to the survey, 63 percent do not recommend

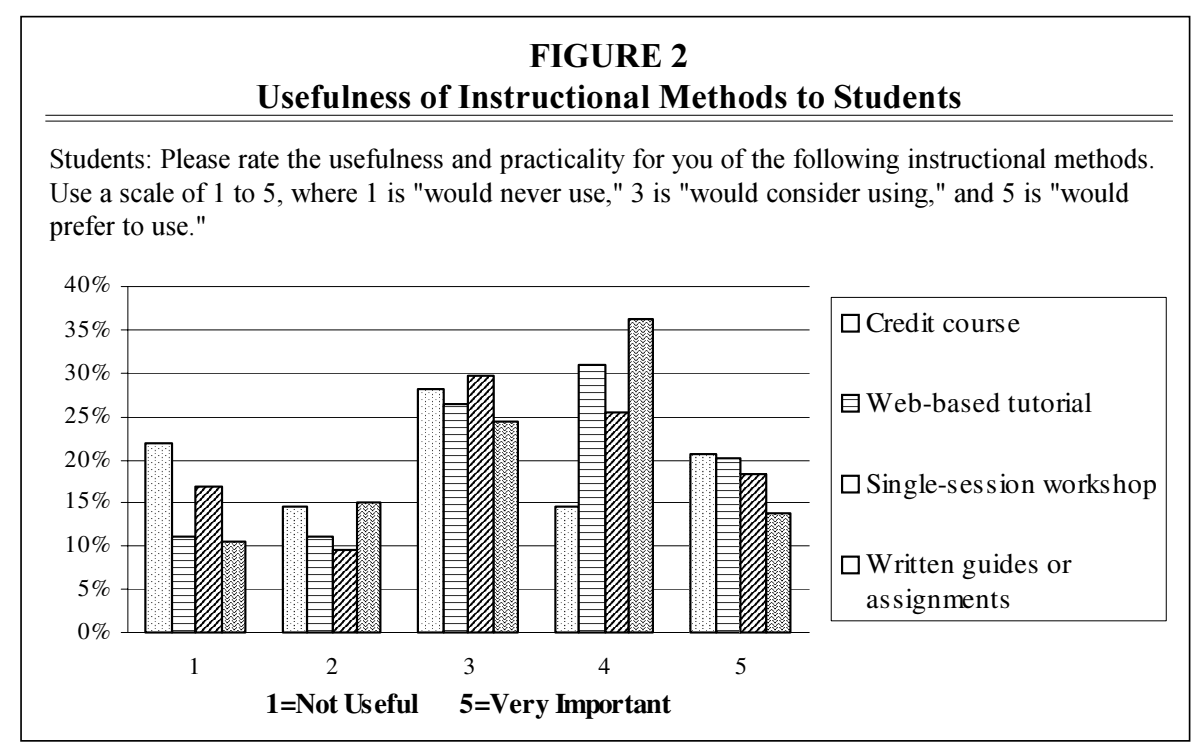




\section{FIGURE 3 \\ Importance of Different Types of Instruction to Faculty}

Faculty: Please rate the importance of having instruction in the following areas available to your students. Use a scale of 1 to 5 , where 1 is "not useful" and 5 is "very important."

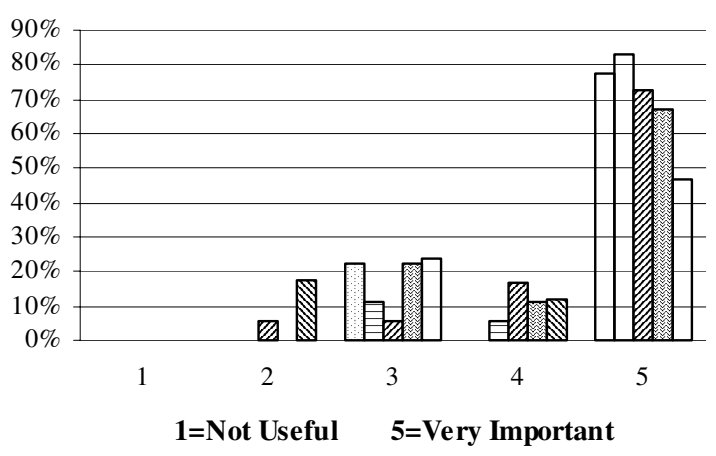

$\square$ Finding library materials

$\square$ Use of electronic resources

$\square$ Use of Internet/WWW

$\square$ Search strategies

$\square$ Evaluating information the courses to their students. For those not recommending the courses, 45 percent indicated the courses were not relevant to what they teach, 33 percent were unaware of them, and 22 percent indicated other reasons for not recommending.

Unlike the general faculty response, 74 percent of the departmental faculty, chairs, and head advisors do recommend the courses with 77 percent being aware of them. Only 13 percent of departmen- tal faculty, chairs, and advisors indicated that the courses would continue without the librarian as the instructor and 39 percent did not know whether the courses would continue. Chemistry and English faculty commented that the quality of the courses was directly related to having librarians as instructors for these courses. Those indicating that the course would continue were primarily from the English department where the course is a requirement for the major.

\section{FIGURE 4}

\section{Usefulness of Training Methods to Faculty}

Faculty: Please rate the usefulness and practicality of the following training methods for your students. Use a scale from 1 to 5 where 1 is "would never use," 3 is "would consider using," and 5 is "would prefer to use."

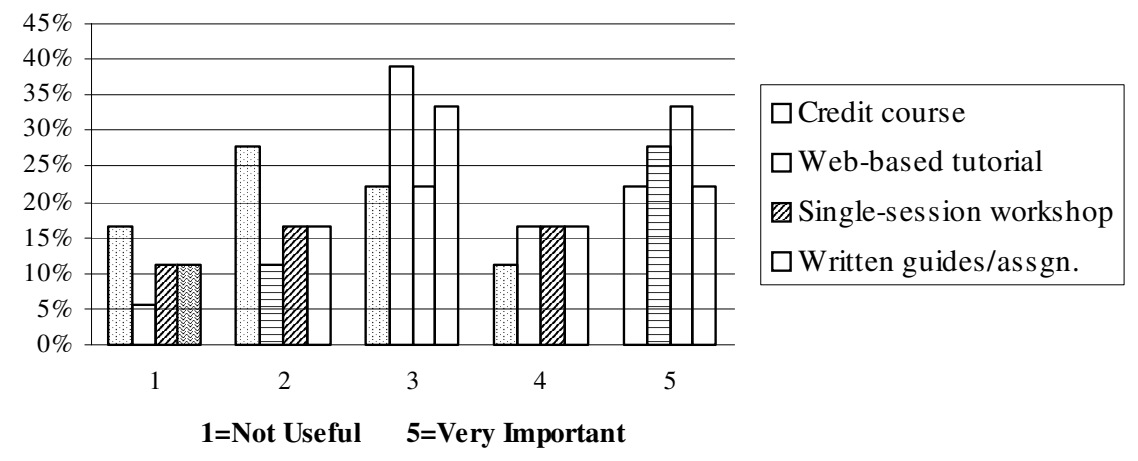




\section{FIGURE 5 \\ Importance of Teaching Credit Courses to Librarians}

Librarians: Please rate the importance of librarians and IS faculty teaching credit courses in meeting the goals and mission of the university and in professional development and scholarship.

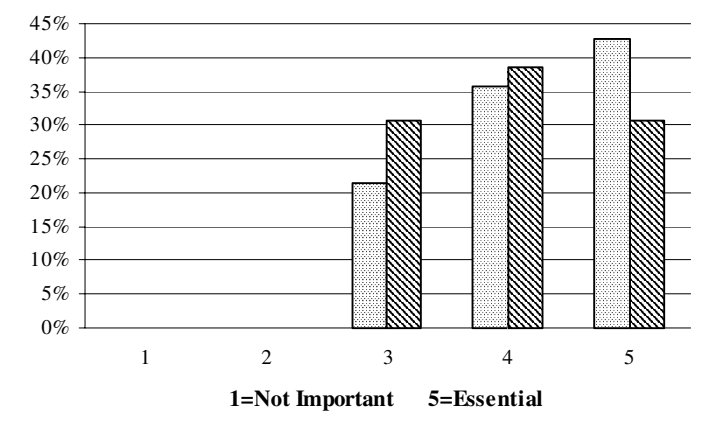

Meeting the goals \& mission of the university

\$ Profes sional development \& scholarship

\section{Internal Stakeholders}

Librarians clearly perceive teaching credit classes as very important in meeting the university's educational mission and goals (see figure 5). IS managers did not perceive the teaching of credit classes to be nearly as important. Half of the sponsors responding rated this at two and the remaining respondents split at three and four (one is "not important" and five is "essential"). Reference staff also consider credit classes to be important for the professional devel- opment of the teaching librarian. The managers were clearly ambivalent on this, as they were unanimous in rating it at three. In addition, 79 percent of the reference librarians responding felt that teaching credit courses is politically important, 14 percent disagreed, and 7 percent thought it might be. Managers were split on the political importance: one said no, one maybe, and two yes (one with the comment, "Only if it is well known across campus that this is done.").

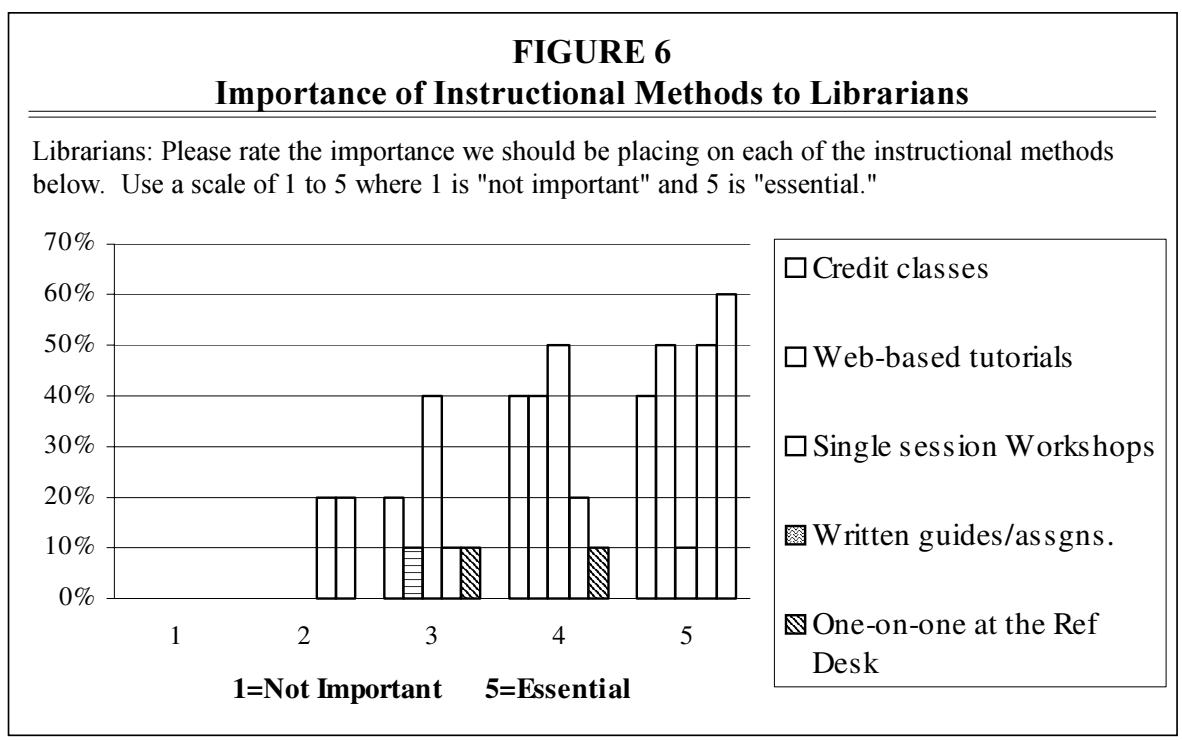


Although reference librarians find written guides and/or assignments and one-on-one instruction at the reference desk to be among the least useful $(20 \%$ rated two where one is "not important" and five is "essential"), they also consider one-on-one instruction at the reference desk the single most essential teaching method ( $60 \%$ rated this "essential"), followed closely by written guides (50\%) and/or assignments and Web-based tutorials (see figure 6). Credit classes are clearly considered as a viable option $(80 \%$ rated this at four or better), although perhaps not as important as other methods. Only 23 percent of the reference staff felt it was necessary for other staff to make up time for librarians teaching credit classes, whereas none of the managers thought this was necessary.

The estimated yearly cost for the credit courses provided by Oregon State University Libraries in 1997-1998 included: personnel at $\$ 21,950$ (primarily faculty salaries based on one credit hour $=0.10$
FTE), services and supplies at $\$ 700$ (primarily copying/printing costs and online search charges where necessary), capital expense is negligible, and no revenue is generated for the library. Total yearly cost is $\$ 22,650$ for the five courses taught.

The team's ultimate recommendation, however, is that credit-bearing courses do provide an important method for teaching library and research skills and that a strong instructional program should provide this opportunity.

\section{Comparison with Other Institutions}

The results from the phone survey of peer institutions and from the BI-L survey are considered together (see figure 7). A significant majority of institutions responding offer credit classes. Libraries are seldom reimbursed for the costs incurred in offering the classes (only 13\% receive funding). Library faculty develop their courses with very little involvement from

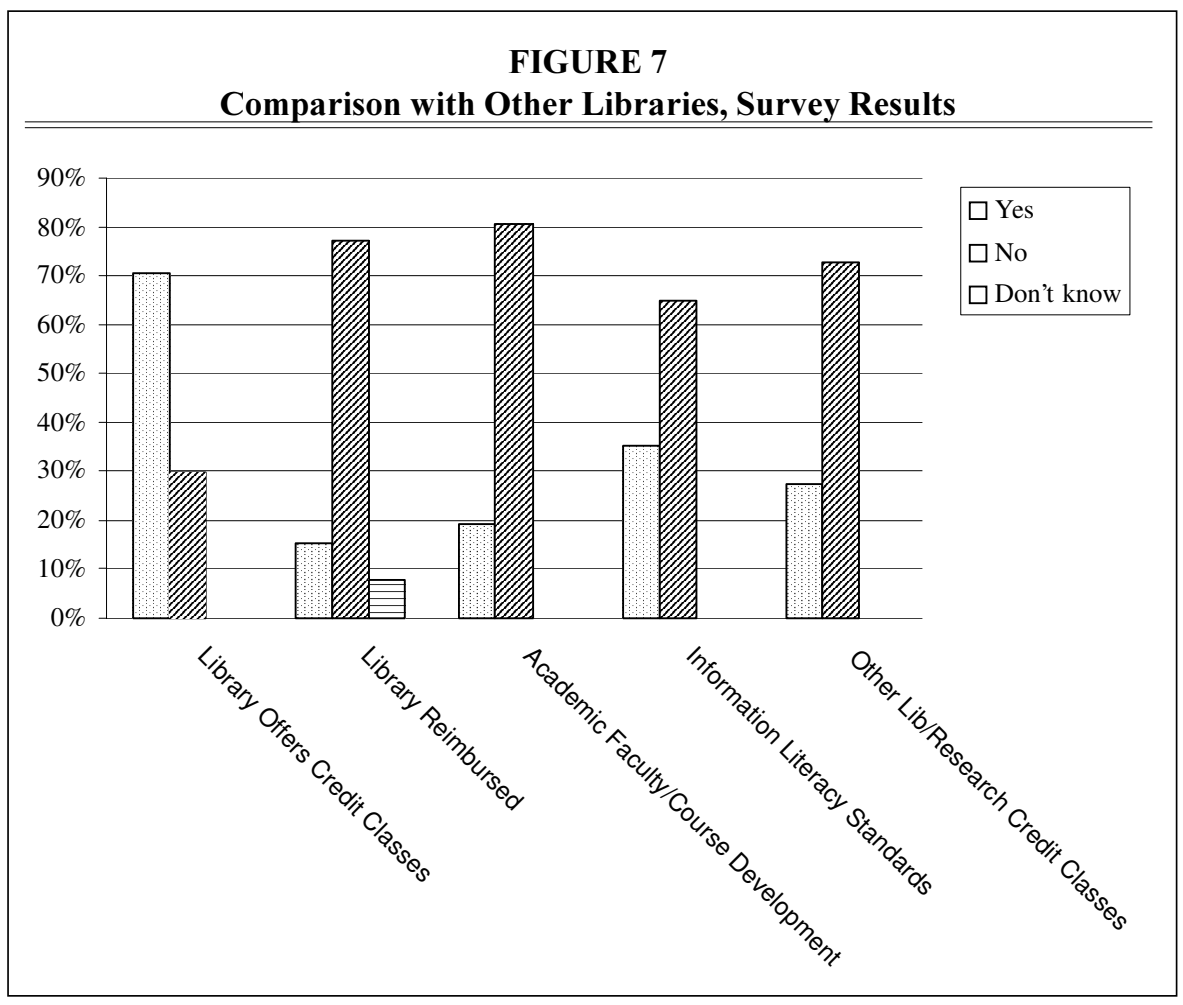


other academic faculty as evidenced by the fact that only 19 percent indicated that other academic faculty are involved in course development. In addition, creditbearing courses focusing on library and research skills are taught primarily by library faculty, as only 27 percent of the institutions responding indicated that other courses with this emphasis exist on campus. Information literacy standards are in place in only 35 percent of the institutions responding, although several others indicated they were in the process of developing them. Oregon State University fits with the majority in all categories. The library offers credit courses for which it receives no reimbursement, library faculty develop their own courses, no other courses on campus focus directly on library or research skills, and information literacy standards are still in the developmental stages.

\section{Final Recommendation}

Based on the information gathered from this variety of sources, a range of viable alternatives for instruction exists, including integrating instruction into existing courses, Web-based tutorials, handouts, workshops, and so on. The team's ultimate recommendation, however, is that credit-bearing courses do provide an important method for teaching library and research skills and that a strong instructional program should provide this opportunity.

The final recommendations to the IS managers included:

- Continue to offer Chemistry 507 and English 200. Explore ways that the academic departments may be able to help the library defray costs and continue to offer the courses.

- Honor commitments made for the remainder of the 1997-1998 academic year and for 1998-1999. If enrollment for the electives does not meet an agreed-upon benchmark, discontinue the course.

- Refer this report and the information gathered by the review group to work groups in reference and instruction for follow-up. They should develop a plan for marketing the courses and assessing effectiveness and should identify ways to reach more students.

- Because of its university-wide nature, explore possibilities for receiving revenue generated by student FTE in ALS 112 course, if enrollment warrants course continuation.

\section{Discussion and Conclusion}

Students and faculty consider instruction in library and research skills important. This study confirmed the need for a variety of instructional methods, including credit courses. Although credit courses were the least preferred method for students, nearly two-thirds would consider a credit course, especially if its relevance to their curricular needs is clear.

The library's challenge lies in helping students to recognize the relevance of the credit courses offered. For courses that are not required, students often rely on subject area faculty members' recommendations. Department chairs and head advisors were largely aware of the library's classes, but this awareness clearly did not "trickle down" to the faculty as a whole. Nearly a third of faculty who did not recommend the courses did not due to a lack of awareness of the courses' existence. In addition, the 45 percent of faculty who did not consider the courses relevant to what they taught suggests that faculty may need additional information on the content of the courses to make the relevance apparent.

There is a clear need to market the library's credit-bearing classes to academic faculty as well as to students. A faculty member's recommendation to a student to take a course is critical to promoting these courses successfully. Higher enrollments tend to be found in those departments where courses are actively recommended or required (such as chemistry and English, respectively). Those courses for entire colleges, such as engineering and agriculture, had less overall faculty awareness of the courses as well as less knowledge of the course content. 
The classes taught for departments (as opposed to colleges) were less inclined to let the class disappear. The departments felt that the expertise of the librarian was an important aspect of the quality of the course. They did not feel the department had faculty equally qualified to teach the courses.

The process of assessing the service itself served as a marketing tool.
Enrollment in CH 507 and Engr 485/ 585 increased markedly during the term following the assessment. Faculty gained knowledge of relevant courses offered through other departments. For example, the $\mathrm{CH} 507$ course had added enrollment from students in the School of Pharmacy during the term following the assessment.

\section{Notes}

1. Linda Shirato and Joseph Badics, "Library Instruction in the 1990's: A Comparison with Trends in Two Earlier LOEX Surveys," Research Strategies 15, no. 4 (1997): 223-37.

2. Ibid., 234.

3. See, for example, Richard J. Wood, "The Impact of a Library Research Course on Students at Slippery Rock University," Journal of Academic Librarianship 10, no. 5 (Nov. 1984): 278-84; Virginia Frank McQuistion, "The Credit Course: Reaffirmation from Two University Libraries. Measurement: Millikin University," Research Strategies 2, no. 4 (fall 1984): 166-71.

4. For example, Tom Gilson, "Library Instruction for Credit: A Technology Driven Need," Research Strategies 15, no. 4 (1997): 279-86.

5. Barbara Wittkopf, "A Look at the State of BI Credit Courses in the ARL-Member Libraries," Research Strategies 9, no. 4 (fall 1991): 162-63.

6. Information Services at OSU includes the OSU Libraries, Telecommunications, Computing Services, and the Communications Media Center. 